Springer Link

Search

- Full Research Article

- Published: 04 January 2021

\title{
Multi-objective optimization of machining factors on surface roughness, material removal rate and cutting force on end-milling using MWCNTs nano-lubricant
}

- I.P. Okokpujie,

- O.S. Ohunakin \&

- C. A. Bolu

Progress in Additive Manufacturing volume 6, pages155-178(2021) Cite this article

- 102 Accesses

- Metricsdetails

\section{Abstract}

The art of nano-additive manufacturing in developing advanced mechanical components via machining cannot be over-emphasized when developing mechanical parts for aerospace, automobile, and structural application through the end-milling of aluminum alloys. However, the end-milling process generates heat and friction due to the machining parameter that initiated the contact between the cutting tool and the workpiece. This excess heat leads to high surface roughness (SR), low material removal rate (MRR), and high cutting force (CF). This study aimed to resolve the machining parameters and the material adhesion by carrying out an experimental evaluation with multiobjective optimization of the machining factors on end-milling of AL8112 alloy using copra oil-based multi-walled carbon nanotube (MWCNTs) nanolubricant. The nano-lubricant preparation was done using the two-step method, and nano-lubricants were implemented via the minimum quantity 
lubrication (MQL) method with the five machining factors. Additionally, the multi-objective optimization and prediction study was achieved using the ramp and desirability bar plot for the three responses, i.e., SR, MRR, and CF under the quadratic rotatable central composite design (QRCCD). The multiobjective optimization result shows that the minimum SR of $1.16 \mu \mathrm{m}$, maximum MRR of $52.1 \mathrm{~mm} / \mathrm{min}$, and minimum CF of $33.75 \mathrm{~N}$ was obtained at the optimized machining factors. Furthermore, the models predicted the experimental results accurately. In conclusion, the multi-objective optimization with copra oil-based MWCNT's-nano-lubricant enhanced machine parts' production for sustainable additive manufacturing.

This is a preview of subscription content, access via your institution.

\section{References}

1. 1.

Rapeti P, Pasam VK, Gurram KMR, Revuru RS (2018) Performance evaluation of vegetable oil-based nano cutting fluids in machining using a grey relational analysis-a step towards sustainable manufacturing. J Clean Prod 172:2862-2875

\section{Article Google Scholar}

2. 2.

Okokpujie I, Okonkwo U, Okwudibe C (2015) Cutting parameters effects on surface roughness during end milling of aluminum 6061 alloy under dry machining operation. Internat J Sci Res 4(7):2030-2036

\section{Google Scholar}

3. 3 . 
Sharma S, Kumar R, Gaur A (2015) A model for magnetic nanoparticle transport in a channel for targeted drug delivery. Proc Mater Sci 10:4449

\section{Article Google Scholar}

\section{4 .}

Okokpujie IP, Ohunakin OS, Adelekan DS, Bolu CA, Gill J, Atiba OE, Aghedo OA (2019) Experimental investigation of nano-lubricants effects on temperature distribution of mild steel machining. Proc Manufact 35:1061-1066

\section{Article Google Scholar}

5. 5 .

Gugulothu S, Pasam VK (2020) Testing and performance evaluation of vegetable-oil-based hybrid nano cutting fluids. J Test Eval 48:5

\section{Article Google Scholar}

6. 6 .

Liu MS, Lin MCC, Tsai CY, Wang CC (2006) Enhancement of thermal conductivity with $\mathrm{Cu}$ for nanofluids using chemical reduction method. Int J Heat Mass Transf 49(17-18):3028-3033

\section{Article Google Scholar}

7. 7 .

Lee CG, Hwang YJ, Choi YM, Lee JK, Choi C, Oh JM (2009) A study on the tribological characteristics of graphite nano lubricants. Internat J Precis Eng Manufact 10(1):85-90 


\section{Article Google Scholar}

8. 8 .

Najiha MS, Rahman MM, Kadirgama K (2016) Performance of waterbased $\mathrm{TiO} 2$ nanofluid during the minimum quantity lubrication machining of aluminum alloy, AA6061-T6. J Clean Product 135:16231636

\section{Article Google Scholar}

9. 9.

Okonkwo UC, Okokpujie IP, Sinebe JE, Ezugwu CA (2015) Comparative analysis of aluminum surface roughness in end-milling under dry and minimum quantity lubrication (MQL) conditions. Manufact Rev 2(30):115

\section{Google Scholar}

10.10.

Pereira O, Martín-Alfonso JE, Rodríguez A, Calleja A, FernándezValdivielso A, De Lacalle LL (2017) Sustainability analysis of lubricant oils for minimum quantity lubrication based on their tribo-rheological performance. J Clean Prod 164:1419-1429

\section{Article Google Scholar}

11.11.

Tazehkandi AH, Shabgard M, Pilehvarian F (2015) On the feasibility of a reduction in cutting fluid consumption via a spray of biodegradable 
vegetable oil with compressed air in machining Inconel 706. J Clean Prod 104:422-435

\section{Article Google Scholar}

12.12.

Junior ASA, Sales WF, da Silva RB, Costa ES, Machado ÁR (2017) Lubricooling and tribological behavior of vegetable oils during milling of AISI 1045 steel focusing on sustainable manufacturing. J Clean Prod 156:635-647

\section{Article Google Scholar}

13.13.

Nandakumar A, Rajmohan T, Vijayabhaskar S (2019) Experimental evaluation of the lubrication performance in MQL grinding of Nano SiC reinforced Al matrix composites. Silicon 1:1-13

\section{Google Scholar}

14.14.

Das A, Patel SK, Biswal BB, Sahoo N, Pradhan A (2020) Performance evaluation of various cutting fluids using MQL technique in hard turning of AISI 4340 alloy steel. Measurement 150:107079

\section{Article Google Scholar}

15.15.

Agrawal SM, Patil NG (2018) Experimental study of non-edible vegetable oil as a cutting fluid in the machining of M2 Steel using MQL. Proc Manufact 20:207-212 


\title{
Article Google Scholar
}

16.16.

\begin{abstract}
Abubakar S, Azwadi CN, Ahmad A (2016) The use of Fe3O4-H2O4 nanofluid for heat transfer enhancement in rectangular microchannel heatsink. J Adv Res Mater Sci 23:15-24
\end{abstract}

\section{Google Scholar}

17.17.

Anil KC, Vika MG, Teja BS, Rao KS (2017). Effect of cutting parameters on surface finish and machinability of graphite-reinforced Al-8011 matrix composite. In IOP Conference Series: Materials Science and Engineering (p. 012025). IOP Publishing.

18.18.

Ali H, Babar H, Shah T, Sajid M, Qasim M, Javed S (2018) Preparation techniques of $\mathrm{TiO}_{2}$ nanofluids and challenges: a review. Appl Sci 8(4):587 Article Google Scholar

19.19.

Chen M, Liu G, Dang J, Li C, Ming W (2018) Effects of tool helix angles on machined surface morphology in tilt side milling of cantilever thinwalled plates. Procedia CIRP 71:93-98

\section{Article Google Scholar}

20.20 . 
Gutnichenko O, Bushlya V, Bihagen S, Ståhl JE (2018) Influence of GnP additive to vegetable oil on machining performance when MQL-assisted is turning Alloy 718. Proc Manuf 25:330-337

\section{Google Scholar}

21.21

Li M, Yu T, Yang L, Li H, Zhang R, Wang W (2019) Parameter optimization during minimum quantity lubrication milling of TC4 alloy with graphene-dispersed vegetable-oil-based cutting fluid. J Clean Product 209:1508-1522

\section{Article Google Scholar}

22.22.

Khalil ANM, Azmi Al, Murad MN, Ali MAM (2018) The effect of cutting parameters on cutting force and tool wear in machining Nickel-Titanium shape memory alloy ASTM F2063 under minimum quantity nano lubricant. Proc CIRP 77:227-230

\section{Article Google Scholar}

23.23.

Bai W, Roy A, Sun R, Silberschmidt VV (2019) Enhanced machinability of SiC-reinforced metal-matrix composite with hybrid turning. J Mater Process Technol 268:149-161

\section{Article Google Scholar}

24.24. 
Basar G, Kirli Akin H, Kahraman F, Fedai Y (2018) Modeling and optimization of face milling process parameters for AISI 4140 steel. Tehnički Glasnik 12(1):5-10

\section{Article Google Scholar}

25.25 .

Duc TM, Long TT, Dong PQ (2019) Effect of the alumina nanofluid concentration on minimum quantity lubrication hard machining for sustainable production. Proceedings of the Institution of Mechanical Engineers, Part C: Journal of Mechanical Engineering Science, 0954406219861992.

26.26 .

Huang WT, Liu WS (2016) Investigations into lubrication in grinding processes using MWCNTs nanofluids with ultrasonic-assisted dispersion. J Clean Product 137:1553-1559

\section{Article Google Scholar}

27.27.

Lawal SA, Choudhury IA, Nukman Y (2014) Evaluation of vegetable and mineral oil-in-water emulsion cutting fluids in turning AISI 4340 steel with coated carbide tools. J Clean Product 66:610-618

\section{Article Google Scholar}

28.28 .

Shukla A, Kotwani A, Unune DR (2020) Performance comparison of dry, flood, and vegetable oil-based minimum quantity lubrication 
environments during CNC milling of aluminium 6061. Mater Today Proc 21:1483-1488

\section{Article Google Scholar}

29.29 .

Prajina NV (2013) Multi response optimization of CNC end milling using response surface methodology and desirability function. Internat J Eng Res Technol 6(6):739-746

\section{Google Scholar}

30.30.

Okokpujie IP, Okonkwo UC (2015) Effects of cutting parameters on surface roughness during end milling of aluminum under minimum quantity lubrication (MQL). Internat J Sci Res 4(5):2937-2942

\section{Google Scholar}

\subsection{1.}

Reddy BS, Kumar JS, Reddy KVK (2011) Optimization of surface roughness in CNC ends milling using response surface methodology and genetic algorithm. Internat J Eng Sci Technol 3(8):102-109

\section{Google Scholar}

32.32.

Gupta MK, Jamil M, Wang X, Song Q, Liu Z, Mia M, Imran GM (2019) Performance evaluation of vegetable oil-based nano-cutting fluids in environmentally friendly machining of inconel-800 alloy. Materials 12(17):2792 


\section{Article Google Scholar}

33.33.

Yung-Chih L, Kung-Da W, Wei-Cheng S, Pao-Kai H, Jui-Pin H (2020)

Prediction of surface roughness based on cutting parameters and machining vibration in end milling using regression method and artificial neural network. Appl Sci 10:3941. https://doi.org/10.3390/app10113941

\section{Article Google Scholar}

34.34.

Sharma AK, Tiwari AK, Dixit AR, Singh RK, Singh M (2018) Novel uses of alumina/graphene hybrid nanoparticle additives for improved tribological properties of lubricant in turning operation. Tribol Int 119:99-111

\section{Article Google Scholar}

35.35.

Azwadi CN, Adamu I, Jamil M (2016) Preparation methods and thermal performance of hybrid nanofluids. J Adv Rev Sci Res 24(1):13-23

\section{Google Scholar}

36.36.

Arnault JC (Ed) (2017) Nanodiamonds: advanced material analysis, properties, and applications. William Andrew.

37.37. 
Okokpujie IP, Ajayi OO, Afolalu SA, Abioye AA, Salawu EY, Udo M, Ikumapayi OM (2018) Modeling and optimization of surface roughness in end milling of aluminum using least square approximation method and response surface methodology. Internat J Mech Eng Technol (IJMET) 9(1):587-600

\section{Google Scholar}

38.38 .

Okokpujie IP, Bolu CA, Ohunakin OS, Akinlabi ET, Adelekan DS (2019) A Review of recent application of machining techniques, based on the phenomena of CNC machining operations. Proc Manuf 35:1054-1060 Google Scholar

39.39.

Agu CK, Lawal SA, Abolarin MS, Agboola JB, Abutu J, Awode El (2019) Multi-response optimization of machining parameters in turning AISI 304L using different oil-based cutting fluids. Niger J Technol 38(2):364375

\section{Article Google Scholar}

40.40 .

Okokpujie IP, Bolu CA, Ohunakin OS (2020) Comparative performance evaluation of $\mathrm{TiO}_{2}$, and MWCNTs nano-lubricant effects on surface roughness of AA8112 alloy during end-milling machining for sustainable manufacturing process. Internat J Adv Manuf Technol 4:1-25

\section{Google Scholar}


Darshan C, Jain S, Dogra M, Gupta MK, Mia M, Haque R (2019) Influence of dry and solid lubricant-assisted MQL cooling conditions on the machinability of Inconel 718 alloy with the textured tool. Internat J Adv Manuf Technol 4:1-15

\section{Google Scholar}

42.42 .

Okokpujie IP, Ikumapayi OM, Okonkwo UC, Salawu EY, Afolalu SA, Dirisu JO, Ajayi OO (2017) Experimental and mathematical modeling for prediction of tool wear on the machining of aluminum 6061 alloy by high speed steel tools. Open Eng 7(1):461-469

\section{Article Google Scholar}

43.43.

Dong PQ, Duc TM (2019) Performance evaluation of MQCL hard milling of SKD 11 tool steel using MoS2 nanofluid. Metals 9(6):658

\section{Article Google Scholar}

44.44 .

Okokpujie IP, Ohunakin OS, Bolu CA, Okokpujie KO (2018) Experimental data-set for prediction of tool wear during turning of Al-1061 alloy by high speed steel cutting tools. Data Brief 18:1196-1203

\section{Article Google Scholar}

45.45 . 
Davoudinejad A, Li D, Zhang Y, Tosello G (2019) Optimization of corner micro end milling by finite element modeling for thin machining features. CIRP 82:362-367

\section{Article Google Scholar}

46.46 .

Kumar S, Gupta D (2016) To determine the effect of machining parameters on material removal rate of aluminium 6063 using turning on lathe machine. Int J of Multidiscip Curr Res 4:688-691

\section{Google Scholar}

47.47.

Badrinathan KS, Karunamoorthy $L$ (2013) Study the effect of progressive feed rate on the cutting force in CNC ends milling AISI 1045 steel. Internat J Eng Technol 5(6):4741-4751

\section{Google Scholar}

48.48 .

Kalidass S, Ravikumar TM (2015) Cutting force prediction in the end milling process of AISI 304 steel using solid carbide tools. Int J Eng Trans A 28(7):1074-1081

\section{Google Scholar}

49.49 .

Hegab H, Darras B, Kishawy HA (2018) Sustainability assessment of machining with nano-cutting fluids. Proc Manuf 26:245-254 


\section{Google Scholar}

50.50 .

Hegab H, Kishawy H (2018) Towards sustainable machining of Inconel 718 using nanofluid minimum quantity lubrication. J Manuf Mater Proc 2(3):50

\section{Google Scholar}

\subsection{1}

Ibrahim MR, Latif AA, Hassan MF, Arifin AMT, Amran AZ, Peter CPE (2017) Effect of feed rate and depth of cut on cutting forces and surface roughness when end milling of mild steel using the NOVIANO cutting tool

52.52.

Ogundimu O, Lawal SA, Okokpujie IP (2018) Experimental study and analysis of variance of material removal rate in high speed turning of AISI 304L alloy steel. Mater Sci Eng 413:1-9

\section{Google Scholar}

53.53.

Ojolo SJ, Adjaottor AA, Olatunji RS (2016) Experimental prediction and optimization of material removal rate during hard turning of austenitic 304I stainless steel. J Sci Technol (Ghana) 36(2):34-49

\section{Article Google Scholar}


54.54.

Asiltürk I, Çunkaş M (2011) Modeling and prediction of surface roughness in turning operations using artificial neural networks and multiple regression methods. Expert Syst Appl 38(5):5826-5832

\section{Article Google Scholar}

55.55.

Kini MV, Chincholkar AM (2010) Effect of machining parameters on surface roughness and material removal rate in finish turning of \pm 30 glass fiber reinforced polymer pipes. Mater Design 31(7):3590-3598

\section{Article Google Scholar}

56.56.

Paturi UMR, Devarasetti H, Narala SKR (2018) Application of regression and artificial neural network analysis in modelling of surface roughness in hard turning of AISI 52100 steel. Mater Today 5(2):4766-4777

\section{Google Scholar}

57.57.

Rahman SS, Ashraf MZI, Amin AN, Bashar MS, Ashik MFK, Kamruzzaman $M$ (2019) Tuning nanofluids for improved lubrication performance in turning biomedical grade titanium alloy. J Clean Product 206:180-196 Article Google Scholar

Download references

\section{Acknowledgments}


The authors wish to appreciate the Covenant University Management for creating a pleasant environment for this research work. The authors also acknowledge the Tower Aluminium Rolling mills, Ota, Ogun State, Nigeria, for providing the aluminium 8112 alloys for this $\mathrm{Ph}$. D research.

\section{Author information}

Affiliations

1. Department of Mechanical Engineering, Covenant University, Ota, Ogun State, Nigeria

I. P. Okokpujie \& O. S. Ohunakin

2. Department of Mechatronics Engineering School of Science and Technology, Pan-Atlantic University, Lekki, Lagos State, Nigeria C. A. Bolu

3. Senior Research Associate, Faculty of Engineering and the Built Environment, University of Johannesburg, Johannesburg, South Africa

O. S. Ohunakin

Corresponding author

Correspondence to I.P. Okokpujie.

\section{Ethics declarations}

Conflicts of interest

The authors declare no conflict of interest.

\section{Rights and permissions}

\section{Reprints and Permissions}

\section{About this article}

Cite this article

Okokpujie, I.P., Ohunakin, O.S. \& Bolu, C.A. Multi-objective optimization of machining factors on surface roughness, material removal rate and cutting 
force on end-milling using MWCNTs nano-lubricant. Prog Addit Manuf 6, 155178 (2021). https://doi.org/10.1007/s40964-020-00161-3

Download citation

- Received13 August 2020

- Accepted01 December 2020

- Published04 January 2021

- Issue DateFebruary 2021

- DOlhttps://doi.org/10.1007/s40964-020-00161-3

Keywords

- Machining

- Surface roughness

- Cutting force

- Material removal rate

- Nano-lubricant

- Quadratic rotatable central composite design

Access options

Buy single article

Instant access to the full article PDF.

$$
34,95 €
$$

Tax calculation will be finalised during checkout.

Buy article PDF

Rent this article via DeepDyve.

Learn more about Institutional subscriptions

Springer Nature

(c) 2021 Springer Nature Switzerland AG. Part of Springer Nature. 
